\title{
Policy responses to IUU fishing in Northern Australian waters
}

\author{
Joanna Vince* \\ School of Government, University of Tasmania, Locked Bag 1340, Launceston 7250, Tasmania, Australia
}

Available online 16 May 2007

\begin{abstract}
Illegal, unreported and unregulated (IUU) fishing activities continue to thrive in the northern region of Australia's Fishing Zone (AFZ). Indonesian fishermen involved in IUU fishing in this area target specific marine species such as shark, reef fish, sea cucumber and trochus that are destined for the Asian market. Many of these marine species' stocks are now at critical levels. Local communities based in Northern Australia, state and Federal governments are also concerned with issues of border security and quarantine measures that coincide with the IUU fishing activities. Whilst Australian and Indonesian governments continue to negotiate this pressing issue, international instruments, bilateral agreements and domestic policies are not deterring Indonesian fishermen from pursuing IUU fishing activities in the AFZ.
\end{abstract}

(C) 2007 Elsevier Ltd. All rights reserved.

\section{Introduction}

Australia's vast ocean domain is made up of 16 million $\mathrm{km}^{2}$ of ocean, an area which is twice the size of the continent's land mass [1]. Australia's Fishing Zone (AFZ) is 8.94 million $\mathrm{km}^{2}$ in area and includes the waters surrounding the offshore territories of the Cocos, Christmas, Norfolk, Macquarie, Heard and McDonald Islands [2]. Legal fishing activities are monitored by the Department of Agriculture, Forestry and Fisheries (DAFF), Australian Fisheries Management Authority (AFMA) on the Commonwealth level and by individual states and territory fisheries agencies under the Offshore Constitutional Settlement (OCS). However, due to the vastness of the fishing zone and

\footnotetext{
${ }^{*}$ Tel.: +61363243262 ; fax: +61363243610 .

E-mail address: joanna.vince@utas.edu.au
} 
the highly prized fish stocks within this area, illegal, unreported and unregulated (IUU) fishing activities are increasing.

According to the Ministerially Led Taskforce on IUU Fishing on the High Seas, illegal fishing

takes place where vessels operate in violation of the laws of a fishery. This can apply to fisheries that are under the jurisdiction of a coastal state or to high seas fisheries regulated by regional organisations. Unreported fishing is fishing that has been unreported or misreported to the relevant national authority or regional organisation, in contravention of applicable laws and regulations. Unregulated fishing generally refers to fishing by vessels without nationality, or vessels flying the flag of a country not party to the regional organisation governing that fishing area or species [3].

This paper focuses on the IUU fishing activities in the northern part of Australia, particularly the northern tip of Western Australia and the north west region of the Northern Territory. The tropical waters in this area are valued for many species of fish including reef fish, shark (specifically caught for shark fin), trochus and trepang (sea cucumber) and are easily accessible by regional neighbours such as Indonesia and Papua New Guinea. Indonesian fishermen have fished the northern region of AFZ for centuries, prior to the enactment of any official boundaries. Traditional fishing by Indonesian fishermen in northern Australian waters has been recognised by the 1974 Memorandum of Understanding (MoU) of Australia and Indonesia which specifies an ocean area called the MoU Box where traditional fishing within the AFZ is permitted. Some Indonesian fishermen, however, are using non-traditional methods to illegally fish in the MoU Box targeting particular marine species to be sold at the wider Asian market which offers high monetary rewards for this effort.

It has been noted on occasions that the fishermen involved in illegal fishing have been reaching Australian shores raising issues about national security, quarantine and customs concerns [4]. On the local level, Australian Aboriginal and fishing communities based on the coast of northern and north western Australia dependent on fishing activities are finding their stocks diminishing due to the illegal practices and are concerned about their livelihoods.

Combating IUU fishing is proving to be a difficult administrative task for local communities, the state and Commonwealth governments and for international organisations. Whilst on the regional level, Australian and Indonesian officials have entered bilateral discussions to work on deterring illegal fishing, the efforts so far have had minimal impact. In the international arena, the issue of IUU fishing is gathering momentum and Australia has partaken in a number of actions with the Food and Agriculture Organisation (FAO), Asia Pacific Economic Cooperation (APEC) and the Organisation for Economic Cooperation and Development (OECD) to combat this activity on an international and regional level.

There has been relatively little interest from political analysts in ocean governance and IUU fishing issues. Ocean governance is often labelled as 'environmental', 'legal' or 'scientific' and an analysis of ocean issues such as IUU fishing from a public policy perspective is underdeveloped. ${ }^{1}$ The aim of this paper is to examine the effectiveness of

\footnotetext{
${ }^{1}$ For exceptions see [5,30].
} 
domestic, regional and international policy responses to IUU fishing in the northern AFZ. It is argued that these policies have not been effective and need to be reviewed and updated to better deter IUU fishing.

\section{Illegal fishing activities in northern Australian waters}

In 2005, 13,018 illegal fishing vessels were sighted in Australian waters and only 600 were apprehended by Australian officials [6]. These vessels range from wooden boats to large fishing ships. In July 2005, for instance, a small wooden fishing boat with five crew members ran aground on North West Crocodile Island, $150 \mathrm{~km}$ north of Darwin. Customs destroyed the fishing boat as it was a quarantine concern "heavily infected by borers and other unidentified marine growths [7]'. Border security and customs concerns are prominent in the apprehension of these fishing vessels as are the illegal fishing activities. Australian Customs boats are fitted with machine guns and it is not unusual for warning shots to be fired to apprehend the illegal fishermen. The fishermen also resort to dangerous tactics to escape being caught including the use of weapons, pit bull dogs on board the vessels and jamming spikes at those attempting to board their vessels [8].

Many of the fishers that illegally fish in the northern part of AFZ are Indonesian. Whilst the following sections of this paper outline the legal framework for which Indonesian fishermen are able to access Australian waters, their illegal fishing activities are elevating. Of particular concern to Australian officials are reports of these illegal fishermen reaching Australian shores. For example, in October 2005, 21 Indonesian fishermen were apprehended at One Arm Point after their boat had been discovered stranded on Brue Reef. The Indonesians hid around the reef and were forced out of hiding when the tide came in. They had taken bags of under and oversize trochus. The Indonesian vessel was intercepted by Customs and destroyed as it was identified as a quarantine risk [4]. Local Aborigines, the Bardi community, are particularly concerned with this incident claiming the Indonesians 'are raping the reef of everything' [4].

There are a number of key reasons for this increase in IUU fishing by the Indonesians. First, their own fish stocks in Indonesian waters are heavily depleted and the fishermen venture to waters with more plentiful stock levels. Second, this activity, whilst dangerous and illegal, has become lucrative because of the high prices and high demand for targeted species. AFMA notes that their fishing methods have become unstainable and some parts of the Indonesian fishing zone have been destroyed due to practices such as the blasting and poisoning of reefs [9].

In addition to the economic factors that make IUU fishing appealing, institutional and social factors are also causes. The cost of labour in Indonesia is very low and Indonesian fishermen risk illegally fishing despite sanctions or imprisonment. They openly acknowledge that they cannot make enough money to survive on 'ordinary' (legal) fishing [10]. Fishermen who are part of the crew of a Flag of Convenience vessel (that do not operate under specific international regulations) are often exposed to minimal health and safety conditions. As Le Gallic and Cox note

The prevalence of a ready and cheap labour pool also reduces in some circumstances the real cost of risk for the vessel owner, as crew members arrested are often abandoned by their employers as they can be replaced at a very low cost...[11] 
The institutional factors that contribute to the cause of IUU fishing occur as a result of the inconsistencies and loopholes in the current international legal framework [11].

\section{International instruments}

IUU fishing is a global issue that is increasingly gathering the attention of coastal states. It has been estimated that the worldwide value of IUU catches is between USD \$4 billion and USD $\$ 9$ billion a year [3,12]. International organisations have attempted to control IUU fishing and despite the legal instruments in place, adopted measures are not always enforced by all states. Australia is involved in a number of key international organisations and is signatory to international instruments that provide the framework for which it has to abide by with regard to IUU fishing. It has been noted in the international arena that Australia finds IUU fishing operations as 'a particularly sensitive issue' [11].

\section{1. $\operatorname{LOSC}$}

The United Nations Convention of the Law of the Sea (LOSC) is the pre-eminent legal framework that outlines the legal parameters of states' activities within their ocean boundaries. Australia ratified the Law of the Sea Convention on 5 October 1994 with the convention entering into force on 16 November 1994, after the 60th document of ratification was lodged [13]. LOSC establishes the universally agreed framework for the determination of boundaries including the exclusive economic zone (EEZ) [14], contiguous zone [15], continental shelves [16] and territorial seas [17]. It also outlines the need for the protection of various marine environments [18] and balances the rights of states to conserve fish stocks [19]. Special regimes for the fishing of anadromous and highly migratory fish species [20] and the management and protection of marine mammals have also been determined by this convention [21].

The consequences of proclaiming a territorial sea and EEZ have made an enormous impact on the claims and responsibility of Australia as a coastal state. It

is now recognised as having authority and responsibility to set total allowable catch, determine national harvesting capacity, and, if a surplus exists beyond that state's harvesting capacity but within the total allowable catch, to grant access to that surplus to fishermen and other states [22].

Juda argues that these changes have significantly impacted on global fisheries management where an estimated 95 per cent of total marine catches occur with national EEZs [22].

Australia's intention to declare an EEZ was announced in 1991 and was formally proclaimed following ratification of LOSC in 1994. Australia's EEZ is the third largest in the world and LOSC provides Australia with the sovereign rights over living and nonliving resources within its boundaries. The Commonwealth did maintain that the continental shelf regime and AFZ (proclaimed in 1979) should be kept completely separate to the EEZ. Although the fishing zone and the EEZ are identical in area the definitions were kept separate to avoid unnecessary amendments to legislation. The new contiguous zone and the EEZ were applied through the Commonwealth's Maritime Legislation Amendment Act 1994. 


\subsection{UNCED and UNFSA}

The United Nations Conference on Environment and Development (UNCED) and subsequent measures have been a vital part of decisions made with regard to IUU fishing. The major outcome of UNCED, Agenda 21, although not legally binding, has strengthened Australia's commitment to ecological sustainable practices in its approach marine management. UNCED was held in Rio de Janeiro on 3-14 June 1992 and it addressed the environmental responsibilities of nation states including their marine and coastal ecosystems. The most significant outcome of this Conference was the new emphasis placed on principled decision making where numerous soft law principles were articulated to guide international and national policy reforms [23].

The outcomes of UNCED included the Rio Declaration; a framework convention on climate change; a framework convention on biodiversity; Agenda 21; a set of non-binding forestry principles; and decisions on future actions [23]. The focus on sustainable development was extended during UNCED to include the precautionary approach/ principle to policy development. The Agenda 21 Action Plan has instigated principles and measures that have been essential to Oceans Policy development in Australia. Of particular importance to ocean resource management are Chapters 2, 14 and 17 of the Action Plan. Chapter 2 deals with trade whilst setting out a number of principles that include making trade and environmental issues 'mutually supportive' [24]. Chapter 14 deals with sustainable development principles while Chapter 17 [25] is holistic in its approach and deals with all aspects of marine and coastal environmental management through 137 recommendations [23].

Chapter 17 addresses fisheries and requires, inter alia, for coastal states to increase fisheries in their EEZ by 'reducing wastage, post-harvest losses and discards [24]'. It calls for flag states to minimise incidental catch, and monitor and set controls for compliance. Three important principles are declared through Chapter 17 that underpin ecologically sustainable development of ocean and marine resources - development must be 'integrated', 'precautionary' and 'anticipatory' [26]. Chapter 17 also declares that

states should convene as soon as possible an inter-governmental conference under United Nations auspices, taking account of relevant activities at the subregional, regional and global levels, with a view to promoting effective implementation of the provisions of the United Nations Convention of the Law of the Sea on straddling fish stocks and highly migratory fish stocks [25].

As a consequence, the United Nations Conference on Straddling Fish Stocks and Highly Migratory Fish Stocks was held through six meetings during the period of 1993-1995. By the time the Conference was completed in 1995 it produced a legally binding instrument, Agreement for the Implementation of the Provisions of the United Nations Convention on the Law of the Sea of 10 December 1982 Relating to the Conservation and Management of Straddling Fish Stocks and Highly Migratory Fish Stocks (also known as the UN Fish Stocks Agreement or UNFSA). The Agreement is nested in the framework established by LOSC, and also reflects the outcomes of UNCED and links the two major international frameworks for Oceans Policy development. ${ }^{2}$ Despite the revision of the document into a

\footnotetext{
${ }^{2}$ Australia ratified the Agreement in December 1999.
} 
legally binding form during the fifth session of the Conference, agreement was still required on the area of enforcement. The states negotiated and resolved the enforcement issue during the sixth session.

UNFSA is a complex document that is made up of 50 articles in 13 parts. Article IV of the Agreement articulates such principles as the use of total allowable catches and quotas, limits to fishing, gear restrictions, seasonal closures and the promotion of optimum utilisation [28]. Article VI of the Agreement also stipulates that party states are to apply the precautionary approach to the management of these fish stocks whilst articles 8-13 and 17 deal with the coastal states' obligations to Regional Fishery Management Organisations (RFMOs) [29]. States are required to become members of RFMOs or apply for the conservation and management measures established by RFMOs. It is important to note that states need to have a 'real interest' in a fishery if they are to be members of a RFMO [30]. In addition, the Agreement underscores the need for more scientific data and for improved techniques when dealing with risk [22]. The Agreement entered into force on 11 December 2001.

\section{3. $A P E C$}

In the Asia Pacific region, APEC has made especially important decisions regarding IUU fishing through its Marine Resource Conservation Working Group (MRC). The MRC is comprised of representatives from each APEC economy with ocean-related responsibilities. It was established in 1990 to ensure that socioeconomic and environmental considerations are taken into account in the protection of marine resources [31]. The aim of the Group is to implement the APEC Action Plan for Sustainability of the Marine Environment which was endorsed in June 1997. During a meeting of APEC-MRC in May 2001, three key objectives were identified for the implementation of the Action Plan: first, to use integrated approaches to coastal management; second, the prevention, reduction and control of marine pollution; and third, sustainable management of marine resources [32].

Australia's involvement in MRC has been integral to national Oceans Policy development, in particular with the fulfilment of regional objectives. The 18 th meeting of the MRC was held in Phuket, Thailand, in May 2005 and it focused on, inter alia, marine-related natural disasters, sustainable development and introduced alien species [33]. The MRC Group contributes its findings each year to the World Summit on Sustainable Development.

The APEC Fisheries Working Group was established in 1991 and whilst it too recognises the importance of sustainability, it has a particular focus on conservation of fish resources, and 'the development of solutions to common resource management problems [34]'. In its meeting held on the 15-17 May 2005, in Phuket, Thailand, the Fisheries Working Group discussed preparations for the Second APEC Ocean Related Ministerial Meeting (AOMM2). A draft framework for this meeting (Fisheries Working Group Framework Towards the Bali Action Plan) was prepared and delivered to a joint meeting with the MRC Working Group.

The first APEC Ocean Related Ministerial Meeting was held in Korea in 2002 and the Ministers agreed in the Seoul Oceans Declaration on the Domestic and Regional Action number 8, which states that they will aim to 'eliminate IUU fishing activities from the APEC region' [35]. During the second meeting (AOMM2) held in Bali in September 2005, 
the Ministers endorsed the Bali Plan of Action which included a key action on IUU fishing on the regional levels [36]. ${ }^{3}$

\subsection{FAO}

The FAO Code of Conduct for Responsible Fisheries is also an important international instrument dealing with IUU fishing. It 'sets out the principles and international standards of behaviour for responsible practices to ensure the effective conservation, management and development of living aquatic resources' [37]. The Code was unanimously adopted on the 31 October 2005 and the Agreement to Promote Compliance with International Conservation and Management Measures by Fishing Vessels on the High Seas (Compliance Agreement) is the legally binding mechanism of the Code. The Compliance Agreement entered into force on 24 April 2003 and Australia accepted the Agreement on 29 August 2004 [38]. The aim of the Compliance Agreement is to improve the regulation of fishing vessels by increasing flag-state responsibilities. The International Plan of Action to Prevent, Deter and Eliminate IUU Fishing was endorsed by the FAO on 23 June 2001 and is a voluntary instrument within the Code of Conduct. Its main objective is directly aimed at IUU fishing - to prevent, deter and eliminate the activity [37].

\subsection{OECD and the International Ministerial Taskforce on IUU fishing}

The OECD established an International Ministerial Taskforce on IUU Fishing in December 2003 to which Australia is party. The Taskforce also comprises of fisheries ministers from the United Kingdom, New Zealand, Canada, Chile and Namibia. In addition, non-governmental members include the World Wide Fund for Nature (WWF), the World Conservation Union (IUCN) and the Earth Institute. The aim of the Taskforce was to set out a plan that seeks to focus 'practical action' on IUU fishing [39].

The Final Report of the High Seas Taskforce makes a number of recommendations that include: committing resources to the International Monitoring, Control and Surveillance Network; developing a publicly available High Seas Fishing Vessel Information System; promoting broader participation in the UNFSA and FAO Compliance Agreement; development of RFMOs; ${ }^{4}$ adopting and promoting guidelines on flag-state performance; promoting better use of technological solutions and sharing of data [3]. It was anticipated that in March 2006 the United Kingdom was to establish an international coordination unit that would aim to advance the proposals covered in the Final Report [3]. At the time of writing, this unit had not yet been established. The Final Report recommendations could also result in LOSC being amended through conference according to Article $312 .^{5}$

\footnotetext{
${ }^{3}$ See APEC website http://www.apec.org for more information about the Bali Action Plan.

${ }^{4}$ For more information on the RFMO framework see [27].

${ }^{5}$ Article 312 of LOSC states 'after the expiry of a period of 10 years from the date of entry inter office of this Convention, a State Party may, by written communication addressed to the Secretary-General of the United Nations, propose specific amendments to this Convention, other than those relating to activities in the Area, and request the convening of a conference to consider such proposed amendments'; see [40].
} 


\section{Domestic policy framework}

The Australian Commonwealth has exclusive powers, as outlined in Section 51 of the Constitution, through subsections (x) 'fisheries in Australian waters beyond territorial limits' and (xxix) 'external affairs' that apply to Commonwealth activities over the offshore. ${ }^{6}$ Australian legal history demonstrates that the Commonwealth was very cautious ${ }^{7}$ using its powers over fisheries matters beyond territorial limits and only did so when necessary. Significantly, it applied this power through the Continental Shelf (Living Natural Resources) Act 1968. The Act was enacted for two distinct purposes, first it ensured that the ratified principles from the 1958 Convention of the Continental Shelf were translated into domestic policy. Second, it brought the continental shelf under Commonwealth jurisdiction and replaced the Pearl Fisheries Act 1952.

Jurisdictional and sectoral disputes over offshore issues were heightened in 1973 when the Commonwealth enacted the Seas and Submerged Lands Act and it rendered state legislation invalid from the low water mark. The Commonwealth gained exclusive sovereignty and jurisdictional rights over all waters up to and beyond the territorial limits and the states had limited control over their offshore resources. As a consequence, this legislation not only affected the offshore oil and mining sector, but also the fishing sector which was managed in territorial waters primarily by the states. The states decided to challenge the validity of Section 51 (xxix) which was used by the Commonwealth as a 'constitutional anchor' for the Seas and Submerged Lands Act [13]. They took their dispute against the Commonwealth to the High Court in the 1975 Seas and Submerged Lands Case [43] where the majority of the Court found that the Commonwealth had sovereign rights from the low water mark and beyond. The High Court upheld Section 51 (xxix) of the Constitution and found that the ruling was valid when based on two international conventions - the 1958 Convention on the Territorial Sea and Contiguous Zone and the 1958 Convention on the Continental Shelf [44].

In its ruling for the Seas and Submerged Lands Case, the High Court found that a revision of the 1967 Petroleum Agreement was necessary. The Commonwealth and states entered detailed negotiations along with the Standing Committee of Commonwealth and State Attorneys General at the Premiers' Conferences in October 1977, 1978 and June 1979. The negotiations resulted in the 1979 OCS which came into force in $1983 .{ }^{8}$ A new fisheries agreement was reached through the OCS which settled state and territory boundary responsibilities from the low water mark to the 3 nautical mile limit [47]. The OCS fisheries 'package', although incomplete, outlined new arrangements for fisheries management between the Commonwealth and the states. The delay in completing the package was a result of the long negotiation process over the classification of fisheries.

The fisheries package introduced flexibility to fisheries management through provisions for individual fisheries and joint authorities where intergovernmental cooperation was

\footnotetext{
${ }^{6}$ The 'territorial limit' refers to a distance 3 nautical miles from the low water mark.

${ }^{7}$ White [41] claims that the Commonwealth was 'leisurely' and Burmester [42] argues that the Commonwealth was 'orthodox' in its approach in linking ratified international agreements to domestic policy.

${ }^{8}$ The Commonwealth government introduced a package of 14 Bills to the House of Representatives on 23 April 1980 which were given the Governor General's assent in May 1980. During this time, the Commonwealth's Attorney General's Department also released a public "kit" that included an explanatory booklet; another booklet that consisted of statements and documents from 1978 to 1979; a map of the Australian continental shelf; and a map of the outer limit of the Australian Fishing Zone. See [45,46].
} 
required [23]. Today, the states are involved in either a single jurisdiction or joint authorities in the management of their fisheries. The OCS package outlined the Commonwealth's fishing responsibilities which included retaining control over the AFZ and transboundary stocks such as the Southern Bluefin Tuna fishery.

The states, conversely, regained their original jurisdiction over territorial waters up to the 3 mile limit and were allocated control of fisheries to the boundary of the AFZ. ${ }^{9}$ The OCS focused primarily on the offshore fisheries disputes, and following this, the AFZ was declared. This influenced the implementation of the fisheries package and the extended zone was announced in November 1979. Nevertheless, the fishing arrangements outlined in the Commonwealth's Fisheries Act 1980 did not enter into force until 1986. The implementation of the fisheries package emphasised many facets of intergovernmental relations. On the one hand, the states and the Commonwealth identified the need for a uniform approach to fisheries management and to establish guidelines against stock decline. On the other hand, the states did not agree to all Commonwealth suggestions in order to protect their own interests [13]. The states found the joint authority approach facilitated by the OCS was adding to, rather than reducing, the existing complexities in fisheries management. A provision in the agreed arrangements further extended the power of the Commonwealth by stipulating that in the event of disagreement within a fisheries authority, the views of the Commonwealth Minister will prevail' [45]. Whilst the OCS does not directly deal with IUU fishing, it remains the key legislative framework dealing with fisheries management arrangements in Australia.

\subsection{FMA}

The Commonwealth's Fisheries Act 1952 was repealed in 1991 by the Fisheries Legislation (Consequential Provisions) Act which provides for the operation of the Fisheries Management Act 1991 (FMA). The FMA has had a number of amendments, the most significant one relating to IUU fishing is the Fisheries Legislation Amendment Act 2004. This amendment translates the FAO Compliance Agreement into domestic policy, however, there are still some inconsistencies between international obligations and Australian legislation. According to Kimpton,

...the FMA proceeds on the basis that a fishing concession is granted to a person...for use on any vessel, while the Compliance Agreement and other treaties assume that authorisation is given to, and can be taken away from, vessels. Some level of drafting creativity has clearly been undertaken in respect of moulding aspects of the Compliance Agreement's obligations into the existing framework [40].

The second amendment of importance to IUU fishing is the Fisheries Legislation Amendment (Compliance and Deterrence Measures and Other Matters) Act 2004. This Act makes new legal provisions to deter illegal fishing activities. First, it increases the maximum fine for an individual involved in illegal fishing activities, and second, it enables Australian authorities to recover the significant cost of a pursuit from the owners of the fishing vessel after it has been apprehended [40].

\footnotetext{
${ }^{9}$ In the case of Bonser v La Macchia 122, CLR (1969), authorises the Commonwealth through Section 51 (x) of the Constitution to legislate with respect to fisheries only beyond the 3 mile limit.
} 
Fishing in Commonwealth waters is managed by the AFMA. AFMA and the Fishing Industry Policy Council of Australia (FIPCA) were established in 1992 through the Fisheries Management and Fisheries Administration Acts 1991. FIPCA was to be responsible for advising the Commonwealth minister on fisheries related issues, however, it was never instituted. Interestingly, the Commonwealth Fisheries Policy Review released in 2003 prepared a similar policy forum [48].

AFMA is responsible for the day-to-day management of Commonwealth fisheries and consults with the Management Advisory Committees (MACs) over fisheries management [49]. AFMA's role is to deter and apprehend illegal foreign fishing activity within the AFZ. It works closely with Coastwatch, Australian Customs Service and the Australian Defence Force in its pursuit of IUU fishing 'managing whole of government maritime surveillance program' [9]. In the northern region of the AFZ, AFMA works with Northern Territory fisheries officers, naval and customs to ensure compliance and enforcement of fisheries laws [50].

\subsection{Australia's Oceans Policy}

The Commonwealth released Australia's Oceans Policy on 23 December 1998. The policy is set out in two volumes, Australia's Oceans Policy and Specific Sectoral Measures $[1,51]$. The aim of the Oceans Policy is to overcome problems perceived to arise from a division of powers and responsibilities leading to jurisdictional overlap and inconsistencies in ocean management. The policy also intends to overcome the problems and limitations imposed by sectoral based management by supporting integration across sectors [52]. The implementation of the Oceans Policy across sectors and jurisdictions has filtered through fisheries policies and the fishing industry is a key stakeholder in Oceans Policy decisions through the National Oceans Advisory Group [53,54]. The Oceans Policy has specific actions regarding IUU fishing including:

- amend the fisheries laws to make surveillance and enforcement of foreign fishing more effective;

- continue to develop national and international strategies dealing with illegal fishing, non-compliance with conventions and enforcement;

- implement the United Nations Agreement on Straddling Fish Stocks and Highly Migratory Fish Stocks [51].

The Commonwealth also released Looking to the Future: A Review of Commonwealth Fisheries Policy in June 2003. The actions from this policy have also set the direction for specific actions dealing with IUU fishing committing Australia to the development of a national action plan for IUU fishing [48].

\subsection{The National Plan of Action for Illegal, Unreported and Unregulated Fishing}

The National Plan of Action for Illegal, Unreported and Unregulated Fishing is Australia's domestic policy response to the International Plan of Action for IUU Fishing and was presented to the FAO on 12 March 2005. The National Plan is divided into five main sections: a description of Australian fisheries and the impact of IUU fishing; principles and strategies; actions to prevent, deter and eliminate IUU fishing; special requirements for 
developing countries; and reporting [50]. The Plan is a whole of government approach that takes into account the IUU fishing across all of Australia's EEZ and AFZ.

The Commonwealth is responsible for the management of 20 per cent of the wild capture fisheries in Australia while the other 80 per cent are managed by the states and the Northern Territory. The value of the whole Australian fishing industry in 2002-2003 was approximately AUD \$2.3 billion [50]. The National Plan has been developed with consultation across sectors and jurisdictions and takes into account states' positions on IUU fishing. The Minister for Fisheries, Forestry and Conservation, Senator Ian Macdonald, claims that the National Plan 'is and will remain, a work in progress' [50]. The Department of Agriculture, Fisheries and Forestry Australia (DAFF) is responsible for policy making to combat IUU fishing activities through the National Plan. It is also responsible for broader fisheries policy, international negotiations (the domestic implementation of the UNFSA with AFMA) and strategic issues [55].

The northern region of the AFZ is recognised in the Plan as a specific area of concern with regard to IUU fishing. The main recommendation for further action in the National Plan regarding the northern AFZ region is for the Australian government to implement new measures for effective fisheries management in the MoU Box (see below) [50].

\section{The Australian and Indonesian fisheries relationship}

The legal relationship between Australia and Indonesia over fishing activities in the Northern AFZ can be traced to 1974, where Australia entered into a MoU with Indonesia as part of negotiations regarding seabed boundaries. This MoU recognises the traditional Indonesian fishermen who have fished the waters of northern Australia long before English settlement in Australia. The MoU enables Australia to manage access in AFZ waters 'while for Indonesia, it enables Indonesian traditional fishers to continue their customary practices and target species such as trepang, trochus, abalone and sponges' [56]. In 1989, the guidelines were amended in the MoU to recognise the 200 nautical mile fishing zones. This area, known as the MoU box, has been severely depleted of several species, such as snapper, which are under the cooperative management of Australia and Indonesia.

Of concern to Australian officials are the high levels of over fishing of other species such as shark (where the fin is taken and the remainder discarded). It has become evident that these species have been fished through non-traditional, illegal methods. The fishing vessels are motorised and there is evidence that advanced global positioning systems (GPS) are also located on board. The National Plan of Action states:

As the waters of the MoU Box have become less productive, this IUU fishing has spread into wider areas of the northern AFZ. Illegal fishing in the northern AFZ is now considered to be a well organised, commercial activity [50].

It is important to note that the Indonesian fishermen fishing in the MoU Box are not subject to Australian fisheries law. The National Plan suggests that one option to deal with this is for all vessels in this area (including foreign vessels) to be authorised to fish in the MoU Box [50].

The legal framework for fisheries cooperation between Australia and Indonesia is the Agreement between the Government of Australia and the Government of the Republic of Indonesia Relating to Cooperation in Fisheries (1992 Fisheries Cooperation Agreement). This agreement, inter alia, outlines the framework for cooperation dealing with illegal 
fishing in northern Australian and southern Indonesian waters [56]. Consultations between both countries under the Agreement have been held annually until 2002, and then were continued through the Australia-Indonesia Working Group on Marine Affairs and Fisheries. The Working Group was established in June 2001 under the auspices of the Australia-Indonesia Ministerial Forum. The Group met for the first time in April 2002 and agreed upon cooperation in the following areas: combating IUU fishing; fisheries management; aquaculture development; the marine environment; marine biotechnology; fishery products; education, training and capacity building; poverty reduction; and marine, coastal and small islands development and management [56].

The Indonesian government has recognised that it requires assistance in the development of sustainable management of its marine resources. On many occasions, Indonesia has required Australian expertise in this area. For instance in June 2003 four officials from the Indonesian Ministry of Marine Affairs and Fisheries visited key Australian ocean and fisheries institutions such as the National Oceans Office. This trip was funded by AusAid and the "visit was intended to help Indonesia build its capacity for marine policy planning and management' [57].

In August 2005, Australian officials met with Indonesian officials in Jakarta to discuss illegal fishing activities. Interestingly, the different interpretations of international law appeared to be an important point of concern for both countries, particularly dealing with border issues [58]. The Commonwealth Government committed AUD \$88 million in October 2005 over 4 years for more border control in the northern part of the AFZ including more naval ships and new customs arrangements to reinstate its concern on IUU fishing [59].

In February 2006, the Australian and Indonesian Foreign Ministers met to discuss illegal fishing in Australia's northern waters and agreed upon joint naval patrols in this area. Extra Customs boats were committed by the Australian government to deter and to apprehend the fishing vessels as stated when funding was approved in October 2005 [60]. This was reiterated on 14 March 2006 with Defence Minister Dr. Brendan Nelson announcing the deployment of Australian naval ships to the northern waters. Joint patrols with the Indonesian navy were once again discussed [61].

Whilst the Indonesian government is interested in eradicating IUU fishing in the MoU Box, Australian officials are conscious of the level of actual commitment that will eventuate from the bilateral discussions. The decisions made at the highest level of government in Indonesia are not always implemented as intended. Indonesian law enforcement and government agencies are often corrupt and ineffective. Dirhamsyah argues that for effective Indonesian participation in maritime surveillance, law enforcement, monitoring and deterrent activities, the following problems need to be addressed. These include, inter alia, a lack of funding, equipment, trained personnel, integrated laws and regulations, coordination, environmental awareness and an inappropriate judicial system [62]. Australia is limited in the way it can assist Indonesia with its domestic problems, and it must be considerate of other policy issues that may affect this fragile bilateral relationship.

\section{Effective policy solutions?}

On the international level, Australia is a member of key organisations that are prioritising IUU fishing. Whilst there has been an enormous effort to combat the activity, 
international law (in particular LOSC) needs to be updated to make a serious impact. The OECD suggests that the aim should be to make IUU fishing activities unprofitable through reducing revenues, reducing the value of catches and increasing costs of IUU vessels [11]. Full state cooperation and enforcement would be required for many of these suggestions from the OECD to be implemented. This would also be a time-consuming process and it is evident that Australia needs to act now. This can be achieved through the domestic policy process and with the help of the Indonesian government.

Australian officials have recognised that the domestic legal framework that deals with illegal fishing needs to be altered. Whilst the recent amendments to the FMA have improved the apprehension of vessels fishing illegally in Australian waters and fines have been increased, there remain loopholes in the legislation. This has been highlighted through the Commonwealth's failure to prosecute an illegal fishing vessel, operating without a current licence, which was apprehended in February 2006. The Chen Long fishing vessel was detected in northern Australian waters carrying 639 tonnes of fish, however, the fish were illegally taken from Indonesian waters not in the AFZ [6]. Current Australian laws prevent the Commonwealth Government from taking action unless there is evidence that the fish were illegally caught in Australian waters. After being detained for 1 month, Chen Long was escorted out of Darwin Harbour by an Australian Navy patrol boat [63]. Officials are concerned that this result will send a message to illegal fishermen that whilst they may get caught, they will not get prosecuted by the Australian government. A Commonwealth Labor Party Taskforce on illegal fishing has claimed that only when the majority of illegal fishermen are caught and prosecuted will foreign fishermen be deterred from illegal activities [61].

Commonwealth agencies are also working to address IUU issues in many different ways. AFMA and the Department of Foreign Affairs and Trade are developing and have begun implementing several initiatives to assist Indonesian fishermen and officials to understand the implications of IUU fishing activities. These include the distribution of free maps and maritime boundaries in Indonesia to fishermen; providing details to Indonesian officials of Indonesian fishermen that have been convicted of illegal fishing activities in the AFZ; developing alternative fisheries projects through AusAid and World Development Bank programs; and plans for cooperative bilateral discussions [9]. AFMA claims that it will take sanctions against fishermen who commit illegal activities in Australian waters [9], however, it does need a stronger commitment from Indonesia to pursue this.

Australian government agencies are in some instances working from a "whole of government' perspective to deal with the IUU issue. Similar to the approach taken with the implementation of Australia's Oceans Policy (see [52-54]), there needs to be coordination not only across agencies, but also across jurisdictions. Local Aboriginal communities have alerted Customs of foreign fishing vessels on a number of occasions. ${ }^{10}$ Working with local communities, from the 'bottom-up' is one domestic solution that can be implemented quickly to combat the large issue of IUU fishing.

\footnotetext{
${ }^{10}$ Another occasion of local community help in the apprehension of illegal fishers occurred in March 2006. The illegal fishing boat was sighted 1.6 nautical miles off Cape Leveque in Western Australia. See [64].
} 


\section{Conclusion}

Whilst it is naïve to assume that IUU fishing in the northern AFZ can completely be eradicated, serious efforts can be made to make this activity less attractive and lucrative to those involved. This paper has demonstrated that there are many policies in place on both the international, regional and domestic levels that do attempt to deal with the severity of IUU fishing, however, they are having little effect as deterrents. This is, unfortunately, a race against time where procrastination over policy change may result in negative economic, social and environmental impacts for both Australia and Indonesia. Despite Indonesia's difficulties with its domestic administration and law enforcement processes, cooperation on this issue of IUU fishing with Australia needs to continue and to be supported by the national, regional and international legal frameworks.

\section{References}

[1] Commonwealth of Australia. Australia's oceans policy: caring, understanding and using wisely. Canberra: AGPS; 1998.

[2] Department of Agriculture, Fisheries and Forestry. The Australian Fishing Zone \& Economic Exclusion Zone. Available from: 〈http://www.affa.gov.au/content/output.cfm?ObjectID =D2C48F86-BA1A-11A1A2200060B0A00877〉. Date cited: 30 March 2006.

[3] High Seas Taskforce. Closing the net: stopping illegal fishing on the high seas. Summary recommendations. UK: UK Department for Environment, Food and Rural Affairs; 2006.

[4] Dodd M. Aborigines up in arms at rape of reef. Australian. 25 October 2005.

[5] Haward M. Policy responses to IUU fishing. Paper presented at Outlook 2004, Canberra 2-3 March 2004.

[6] Michelmore K. NT: Govt red faced as massive fishing vessel slips through net. AAP General News Wire, Sydney, 10 March 2006.

[7] Anon. Illegal fishing boat destroyed by customs officials. Adelaide: Australian Associated Press Pty Limited; 2005. 17 July.

[8] Murdoch L. A shot across the bows for illegal fishing boats. Sydney Morning Herald, 29 September 2005.

[9] Australian Fisheries Management Authority. Illegal Foreign Fishing. Available from: 〈http://www.afma.gov.au/management/compliance/illegal/default.htm $\rangle$, date cited: 21 March 2006, date last modified 22 November 2005.

[10] Powell S. Fishermen caught by the lure of the fin. Australian, 24 October 2005.

[11] Le Gallic B, Cox A. An economic analysis of illegal, unreported and unregulated (IUU) fishing: key drivers and possible solutions. Marine Policy 2006;30(6):689-95.

[12] Sumaila UR, Alder J, Keith H. Global scope and economics of illegal fishing. Marine Policy 2006;30(6):696-703.

[13] Rothwell D, Haward M. Federal and international perspectives on Australia's maritime claims. Marine Policy 1996;20(1):29-46.

[14] LOSC, Articles 55-75.

[15] LOSC, Article 33.

[16] LOSC, Articles 76-85.

[17] LOSC, Articles 2-32.

[18] LOSC, Articles 192-237.

[19] LOSC, Articles 116-119.

[20] LOSC, Articles 64-67.

[21] LOSC, Articles 65 and 120.

[22] Juda L. The 1995 United Nations Agreement on straddling fish stocks and highly migratory fish stocks: a critique. Ocean Development and International Law 1997; $28: 147$.

[23] Kriwoken L, Haward M, VanderZwaag D, Davis B, editors. Oceans law and policy in the Post UNCED Era: Australian and Canadian Perspectives. London: Kluwer Law International; 1996.

[24] Bergin A, Haward M. International environmental conventions and actions - implications for the fishing industry. In: Proceedings outlook conference 1995, Canberra 7-9 February, 1995. p. 282. 
[25] United Nations. Agenda 21: Programme of action for sustainable development and the UNCED proceedings. New York: Oceana, 1992. [Chapter 17].

[26] Herriman M, Tsamenyi M, Ramli J, Bateman S. Australia's oceans policy: international agreements, Background paper 2. A Report Commissioned by Environment Australia, October 1997.

[27] Erceg D. Deterring IUU fishing through state control over nationals. Marine Policy 2006;30(2):173-9.

[28] United Nations. Convention on the conservation and management of straddling fish stocks on the high seas and highly migratory fish stocks on the high seas. New York: UN Department of Public Information; 1995.

[29] Haward M. Management of marine living resources: international and regional perspectives on transboundary issues. In: Blake G, Chia L, Grundy-Warr C, Pratt M, Schofield C, editors. International boundaries and environmental security: frameworks for regional cooperation. Great Britain: Kluwer Law International; 1997. p. 46.

[30] Haward M. IUU fishing: contemporary practice. In: Oude AG, Rothwell DR, editors. Oceans management in the 21st century: international frameworks and responses. Netherlands: Koninklijke; 2004. p. 87-106.

[31] APEC. Working Groups and Expert Groups-MRC. Available from: 〈http://www.apecsec.org.sg/ workgroup/marine_upd.html $\rangle$. Date cited: 1 August, 2002, Date last modified, 16 May, 2002.

[32] APEC. Working Groups and Expert Groups -MRC. Available from: 〈http://www.apecsec.org.sg/ workgroup/marine_upd.html $\rangle$. Date cited: 24 June 2003, Date last modified, May, 2003.

[33] APEC. Marine Resource Conservation Group. Available from:〈http://www.apec.org/apec/apec_groups/ working_groups/marine_resource_conservation.html $\rangle$. Date cited 27 March 2006.

[34] APEC. Fisheries working group. Avvailable from: 〈http://www.apec.org/apec/apec_groups/working_groups/ fisheries.html >. Date cited 27 March 2006.

[35] APEC. APEC Ocean-Related Ministerial Meeting. Available from: 〈http://www.apec.org/apec/ministerial_ statements/sectoral_ministerial/ocean-related.html $\rangle$. Date cited: 27 March 2006.

[36] National Oceans Office. Oceans Action Bulletin. Canberra: 30 September 2005.

[37] Department of Foreign Affairs and Trade. Regulation Impact Statement: FAO Compliance Agreement. Available from: 〈http://beta.austlii.edu.au/au/other/dfat/nia/2002/24/ris.html $\rangle$. Date cited 21 March 2006.

[38] Department of Agriculture, Fisheries and Forestry. FAO Compliance Agreement. Available from: 〈http:// www.affa.gov.au/content/output.cfm?ObjectID = 5C2AFF43-8706-4E3B-B54725C400444470 $\rangle$, date cited: 28 March 2006.

[39] High Seas Taskforce Secretariat. High Seas Taskforce Ministers Announce Joint Initiatives to Tackle Illegal, Unreported and Unregulated Fishing - Final Taskforce Report Launched. Available from: 〈http:// www.high-seas.org >, 3 March 2006. Date cited 29 March 2006.

[40] Kimpton P. Current legal developments: Australia. International Journal of Marine and Coastal Law 2004;19(4):537-43.

[41] White M. Marine pollution laws of the Australasian region. Sydney: The Federation Press; 1994.

[42] Burmester H. Australia and the law of the sea. In: Crawford J, Rothwell D, editors. The law of the sea in the Asia Pacific Region. The Netherlands: Martinus Niijhoff Publishers; 1995.

[43] New South Wales v The Commonwealth (1975) 135, CLR 337.

[44] Rothwell D, Kaye S. A legal framework for integrated oceans and coastal management in Australia. Environmental and Planning Law Journal 2001;18(3):279.

[45] Department of the Attorney General. The offshore constitutional settlement: a milestone in cooperative federalism. Canberra: AGPS; 1980.

[46] Department of the Attorney General. Offshore constitutional settlement: selected statement and documents. Canberra: AGPS; 1980.

[47] Byrne J. The decision making structure for fisheries management. The role of government and states, and commonwealth authorities. In: Australian fisheries conference, Canberra, January 31-February 2, 1985. p. 2.

[48] Commonwealth of Australia. Looking to the future: a review of commonwealth fisheries policy. Canberra: AGPS; 2003 June.

[49] Polson G. Implementing UNCLOS: evolution of national fisheries legislation and management structures. In: Paper presented at the Thirtieth annual conference of the Law of the Sea Institute. Al Ain, United Arab Emirates, 19-22 May, 1996.

[50] Department of Agriculture, Fisheries and Forestry. Australian National Action Plan to prevent, deter and eliminate illegal, unreported and unregulated fishing. Canberra: DAFF; 2005 July.

[51] Commonwealth of Australia Australia's oceans policy: specific sectoral measures. Canberra: AGPS; 1998. 
[52] Vince J. The development of Australia's oceans policy: change and stability in a policy community. Unpublished PhD thesis, University of Tasmania, 2004.

[53] Vince J. Australia's oceans policy: five years of integration across sectors and jurisdictions? Maritime Studies 2003;133:1-13.

[54] Vince J. The south east regional marine plan: implementing Australia's oceans policy. Marine Policy 2006;30(4):420-30.

[55] Australian Fisheries Management Authority. About AFMA. Available from: 〈http://www.afma.gov.au/ about\%20afma/default.php $\rangle$. Date last modified: 2001; Date cited: Monday 26 May 2003.

[56] Department of Agriculture, Fisheries and Forestry. Indonesia - Australia Fisheries Cooperation. Available from:〈http://www.daff.gov.au 〉. Date cited: 21 March 2006.

[57] National Oceans Office. Oceans action bulletin. Commonwealth of Australia: Hobart, 27 June 2003.

[58] Anon. Australia discuss illegal fishing. Jakarta: Financial Times Information Limited; 2005. 24 August.

[59] Senator Macdonald I, Senator Ellison C. Big increase in border protection for northern Australia, Joint Statement Media Release: DAFF, 20 October 2005.

[60] Taylor R. Australian, Indonesia to jointly patrol north despite Papua spat. AAP General News Wire. Sydney: 27 February 2006.

[61] ABC News Online. Nelson to discuss joint illegal fishing patrols with Indonesia. Available from: 〈http:// www/abc.net.au/news/newsitems/200603/s1591359.htm>, 14 March 2006.

[62] Dirhamsyah. Maritime law enforcement and compliance in Indonesia: problems and recommendations. Maritime Studies 2005; September/October: 1-17.

[63] ABC News Online. Chen Long sails away from fishing controversy. Available from: 〈http://www/ abc.net.au/news/newsitems/200603/s1594805.htm >, 17 March 2006.

[64] ABC Online. Aboriginal community praised over suspected illegal fishing tip-off. Available from: 〈http:// www.abc.net.au/news/newsitems/200603/s1583839.htm >. 4 March 2006. 